\title{
Multinational enterprise subsidiaries in local clusters: embeddedness or isolation?
}

\author{
José-Vicente Tomás-Miquel* and \\ Manuel Expósito-Langa
}

Business Administration Department, Universitat Politècnica de València, Plaza Ferrándiz y Carbonell 2, 03801 Alcoy (Alicante), Spain

Email: jotomi@doe.upv.es

Email: maexlan@doe.upv.es

*Corresponding author

\section{José-Antonio Belso-Martínez}

Department of Economics and Finance,

Universidad Miguel Hernández,

Avenida de la Universidad s/n,

03202 Elche (Alicante), Spain

Email: jbelso@umh.es

\section{Francisco Mas-Verdú}

Economics and Social Sciences Department,

Universitat Politècnica de València,

Camino de Vera s/n. 46022 Valencia, Spain

Email: fmas@upvnet.upv.es

\begin{abstract}
Despite the spread of globalisation, industrial clusters remain vibrant spaces for the generation of knowledge and innovation. This has attracted Multi-National Enterprises (MNE) to collocate their subsidiaries in specific geographic spaces and clusters in order to exploit the local resources in the territory. This paper investigates the case of the Valencian Toy Valley Cluster in Spain to demonstrate how MNE subsidiaries are integrated in clusters. The results confirm that MNE subsidiaries develop their networking practices within a limit portfolio of local partners, configuring a club of skilled partners, and integrated mainly by specialised suppliers. This research addresses the research questions using two methods of investigation from international management: social network analysis and non-parametric tests.
\end{abstract}

Keywords: multinational enterprises; industrial clusters; social network analysis.

Reference to this paper should be made as follows: Tomás-Miquel, J-V., Expósito-Langa, M., Belso-Martínez, J-A. and Mas-Verdú, F. (2018) 'Multinational enterprise subsidiaries in local clusters: embeddedness or isolation?', European J. International Management, Vol. 12, Nos. 5/6, pp.624-641. 
Biographical notes: José-Vicente Tomás-Miquel is an Assistant Professor of Business Management at the Polytechnic University of Valencia (Spain). He holds a PhD in Management at Polytechnic University of Valencia (Spain). His research topics are focused on clusters, social capital, knowledge management and network analysis. He has published several contributions in journals such as International Entrepreneurship and Management Journal, Higher Education, Journal of Organizational Change Management and Scandinavian Journal of Management.

Manuel Expósito-Langa is currently an Associate Professor of Management at the Polytechnic University of Valencia (Spain), and has $\mathrm{PhD}$ in Management from Polytechnic University of Valencia (Spain). His research has been focus on industrial districts, social capital, inter and intra-organisational relationships, absorptive capacity and innovation. His papers have appeared in leading journals such as Industry \& Innovation, International Entrepreneurship and Management Journal, Entrepreneurship and Regional Development, Regional Studies, Papers in Regional Science and European Planning Studies.

José-Antonio Belso-Martínez is Professor at the University Miguel Hernández, Spain. He graduated in Economics at the University of Alicante (Spain), and holds a $\mathrm{PhD}$ in Economics from University Miguel Hernández. He is member of the AERT research group, and has also acted as coordinator of several research projects or contracts. His research is mainly focused on geography, innovation, planning and development, economics and business. His research has been awarded by Spanish academic organisations, and has been published in leading journals such as European Planning Studies, European Urban and Regional Studies, Urban Studies, Entrepreneurship and Regional Development, among others.

Francisco Mas-Verdú is currently Professor at the Polytechnic University of Valencia, Spain. He graduated in Economics and in Law at the Universitat de Valencia, Spain, and holds a $\mathrm{PhD}$ in Economics from the Polytechnic University of Valencia. He was the Chair of Studies Service of the IMPIVA, the public institute for the SMEs in the Valencia Region. His research is focused on services sector, industry policy and innovation. He has published numerous works and papers in journals such as Small Business Economics, The Service Industries Journal, Service Business, European Planning Studies and Applied Economic Letters, among others.

\section{Introduction}

Within the post-crisis economy architecture, Multi-National Enterprises (MNEs) and their subsidiaries have become the dominant actors in the global arena and the pillars of many industrial systems. From a territorial perspective, understanding the locational and operational patterns of these actors appears crucial for both managers and policy makers. Awareness of this need has resulted in an extensive academic literature on why and how MNEs collocate in certain geographic areas and, particularly, in industrial clusters (Enright, 2000, Mariotti et al., 2010, Crescenzi et al., 2013). 
Despite the various valuable meticulous descriptions and elaborations about how these territorial agglomerations engender additional sources of competitiveness, there is scant and inconclusive empirical evidence on aspects such as search for specialised suppliers, knowledge spill-overs, and local support organisations. There is a particularly broad consensus on the need for further research into the reasons, configurations and implications of the location patterns of MNEs (Beugelsdijk et al., 2010; McCann and Acs, 2011; Beugelsdijk and Mudambi, 2013) and, especially, location in industrial clusters (Mudambi and Swift, 2012). Only a few studies consider how MNEs are integrated or involved in cluster networks and how their behaviour differs from other co-located companies.

With the dual aim of enhancing the academic state of the art and meeting practitioners needs, this article sheds light on the way MNE subsidiaries become involved in cluster networks vis-a-vis their local counterparts. In addition to examining the main structural characteristics at firm level, we provide some detailed evidence on the particularities of the topography of subsidiary networks, the profiles of local partners and relationship traits.

We conducted an empirical analysis using data collected in the Valencian Toy Valley cluster (Spain), a leading industrial space for innovation and manufacturing subcontracting whose recent trajectory has been shaped by the establishment and operations of foreign MNEs from various industries (Hervás-Oliver and Sempere-Ripoll, 2016).

After an initial qualitative exploration based on in-depth interviews and secondary sources, we used a combination of two research methods to analyse fine grained microlevel data from 75 firms and 10 supporting organisations, collected in face-to-face interviews. Social network analysis provided quantitative information on the intensity and configuration of the business and knowledge flows developed by MNEs in the cluster, while non-parametric tests allowed us to compare the involvement of MNEs and other cluster firms in the industry cluster.

Our findings reveal structural differences in the relational behaviour of MNEs versus other actors in the cluster and, in particular, the selective nature of the networking practices and choice of local partners. MNE subsidiaries are more likely to interact with a limited number of local partners that represent a club of skilled partners dominated by highly integrated and specialised suppliers. These findings extend and corroborate the integrative approach based on the international business and cluster literatures and enhance our understanding of MNEs' co-location decisions and networking activities, which enable the potential of the territory to be exploited. In addition, we provide insights that should be useful for the design of public policies to enable MNEs' successful integration in the local context and to foster knowledge renewal and diffusion. From a firm perspective, our findings should contribute to the definition of strategies aimed at generating synergies and overcoming the barriers to knowledge access.

The paper is structured as follows. Section 2 presents the theoretical framework for this research and defines the research questions. Section 3 describes the research setting and presents the results of the empirical study. Section 4 provides some theoretical and managerial implications and discusses some limitations of this study and recommendations for future research. 


\section{Theoretical background: MNE subsidiaries and industrial clusters}

Although MNEs' home-country operations remain the main source of their knowledge, valuable knowledge can be created at other locations in the MNE network (Meyer et al., 2011). Learning derived from different networks and locations allows the MNE to enlarge its knowledge stock and extend its capabilities (Cantwell, 2009; Collinson and Wang, 2012). Thus, the network of exchange relations involving the parent company, subsidiaries, suppliers, customers and competitors is crucial for the MNE's leadership in value adding activities.

MNE subsidiaries tend to focus on routine replication and local adaptations (Cantwell and Mudambi, 2005, 2011); however, in some cases, subsidiaries may develop and spark innovative activities. In this case, depending on the level of its autonomy, specialisation in a particular segment of the value chain (Mudambi, 2008), appropriate integration in the host territory and strong links to the parent company (Marin and Bell, 2010), the subsidiary becomes the source of the MNE's competitiveness.

On the other hand, industrial clusters, understood as geographically proximate groups of interrelated firms and institutions operating in a specific sector (Porter, 1998), represent areas endowed with particular innovation dynamism. The proximity of the firms belonging to a cluster allows them to benefit from a range of externalities and specific knowledge, which increase their competitiveness and innovativeness.

Generalisations should always be interpreted with some caution, but vibrant clusters tend to include more autonomous and more embedded MNE subsidiaries (Birkinshaw and Hood, 2000), which participate in specific value chains customised to benefit from the local territory (Mudambi and Venzin, 2010). In this context, Tallman and Chacar (2011) propose a framework to describe how MNEs collocate in local networks and highlight the importance of embeddedness with local actors as providing the best access to local knowledge. At the same time, to facilitate the integration of MNEs participating in cluster networks and to enable their access to locally available resources, requires some particular structural characteristics (Birkinshaw and Hood, 2000). Thus, our first research question is:

Research question 1: What are main structural characteristics of MNE subsidiaries in clusters? How do the characteristics of these firms differ from those of other, non-cluster, firms?

Innovative capabilities are crucial for competitiveness, with relevant effects at the territorial level. This has resulted in MNEs' competence creating activities becoming geographically dispersed. MNE subsidiaries located in host countries, build these competencies through specific learning processes, which occur in certain socio-economic contexts (Holm et al., 2003) and work to reinforce the parent firm's stock of capabilities. The intra-MNE network fosters knowledge flows from subsidiaries to parent (Mudambi and Navarra, 2004) and supports a more dynamic relationship among subsidiaries that compete and organise their innovation efforts around elements of the geographically dispersed portfolio of activities. Zangh et al. (2014) suggest that subsidiaries in an MNE network are dependent on the parent firm, but are also interdependent, operating as competence-creating network nodes.

Traditionally, subsidiaries' competence developments have depended largely on knowledge derived from the parent company. Intra-organisational networks act as conduits fostering the accumulation of technological expertise and the subsequent acquisition of capabilities (Almeida and Phene, 2004). However, both internal resources 
and locational advantages are creating knowledge for subsidiaries. On the one hand, dynamic internal capabilities (Amin and Cohendet, 2004) allow enlargement of the organisational knowledge base through cooperation, which is more likely in a context of geographical proximity such as a cluster. On the other hand, subsidiaries that are part of the MNE network have more freedom to explore local knowledge sources and to establish inter-organisational relationships that benefit their capabilities and innovation processes (Figueiredo, 2011).

Autonomy increases the subsidiary's motivation knowledge production (Mudambi et al., 2007) by enhancing its ability to form appropriate networks in its own local environment (Birkinshaw and Hood, 1998; Cantwell and Mudambi, 2005). Collinson and Wang (2012) assess autonomy and self-determination in terms of: input activities (selecting suppliers, hiring senior management, global sourcing strategy); output activities (sales and service, assembly, manufacturing, product development, international strategy development); and internal activities (operations and training). Thus, the second research question we investigate is:

Research question 2: How are MNE subsidiaries involved in cluster networks? What types of ties do they develop?

Subsidiaries require territorial integration and networking to access and exploit local resources (Gertler and Levitte, 2005; Heidenreich, 2012; Beugelsdijk and Mudambi, 2013) and, particularly, complex knowledge, which, often, is embodied in a skilled labour force (Mudambi and Swift, 2012). The stickiness of cluster knowledge to the local context hinders its access beyond cluster boundaries, making co-location essential to obtain the gains from the 'local buzz' (Bathelt et al., 2004). Therefore, location of a subsidiary is guided by the possibility of accessing valuable local knowledge (McCann and Mudambi, 2004), which possibility is boosted by spatial proximity over time, through intensive interactions, shared institutions and trust. The richness of the knowledge available in the cluster and within the MNE firm network, determine the subsidiary's knowledge outcomes (Almeida and Phene, 2004; Marin and Bell, 2010; Figueiredo, 2011).

Such a strategy allows subsidiaries to tap into the resources and knowledge accumulated by firms in other clusters (Enright, 2000; Nadvi and Halder, 2005). The network of parent company and subsidiaries enables the configuration of global knowledge through incoming flows from dispersed geographic areas (Cantwell and Piscitello, 1999) and allows all of the firm's subsidiaries to be potential sources of competitiveness (Mudambi and Navarra, 2004; Cantwell and Mudambi, 2005). The balance between internal organisational fit and embeddedness of the subsidiaries in local networks, shapes the contribution of this global network to MNE's capacity to compete (Narula, 2014).

Based on these arguments, we investigate the follow question:

Research question 3: With whom are MNE subsidiaries connected?

\section{$3 \quad$ Research setting}

\subsection{The Toy Valley}

The Spanish toy industry is an example of persistence in a competitive environment governed by large corporations and Far-east manufacturers. Although a remarkable $61 \%$ 
of exporters achieve export sales of over euro 400 million, the Spanish toy industry is not a major global player. Production is concentrated particularly in the Valencia region, which accounts for roughly $40 \%$ of jobs and total sales in Spain. The Toy Valley cluster is located around four cities in the south of the Valencia region (Ibi, Onil, Castalla and Tibi), and accounts for $98 \%$ of regional economic activity based on specialisation in different types of production for distinct market niches.

This local production system was based on Small and Medium Sized Enterprise (SME) developments and the progressive consolidation of common institutions, which fostered collective efficiency and competitiveness. During the first half of the 20th century, information incoming through various different channels drove a transformation of traditional pottery and tinsmithing activities into toy manufacturing. The availability of raw materials and skilled workers led to entrepreneurial activities in the production and creation of miniatures and dolls in Ibi and Onil. The structural changes brought by the introduction of new materials and technologies (e.g., plastics and injection moulding), resulted in Toy Valley experiencing a golden age in the 1950s. Local entrepreneurs, supported by a growing community of providers and based sometimes on spin-offs, launched several successful projects and established trademarks, many of which, unfortunately, have disappeared as a result of spiralling globalisation.

The vitality of the cluster in more recent times is based on firm proximity and the presence of importing support organisations. Local firms have increased their technological competences and innovation capabilities through collaborations and welldesigned programmes (Albalalejo, 2002). Both AIJU (a toy technological institute) and AEFJ (a business association) act as specialised providers and policy designers. By providing specific services at reasonable cost, AIJU remains a pivotal actor in the construction of firm and systemic capabilities (Holmström, 2006). It serves, also, as a valuable repository of novel knowledge and fosters innovation by providing assistance in the form of product development support, manufacturing and training (Holmström, 2006). AEFJ has made a decisive contribution to local competitiveness and innovation. In addition to providing a variety of services (legal assistance, institutional representation, training), the business association provides a forum for the exchange and diffusion of valuable managerial experience among local firms. Several major projects have made AEFJ pivotal to the development of new products and identification of market trends.

\subsection{Sample and data collection}

We developed a questionnaire building in the literature (Giuliani, 2007; Morrison and Rabellotti, 2009). We address aspects such as firm characteristics, inter-organisational relationships and economic performance. The preliminary questionnaire was slightly modified to account for the few problems encountered during a pilot. We apply a rosterrecall methodology to collect network data. Interviewees were asked to select, from a list of local firms and supporting organisations, which were used to obtain technical knowledge and with which business relationships had been established. ${ }^{1}$ Interviewees were invited to add to this list if there were firms that they used which were not initially included.

To guarantee response accuracy, a local technician involved in the toy industry and innovation programmes, administered the questionnaire to top-level managers and business owners in 45-50 minute face-to-face interviews. At the beginning of each interview, the benefits of the project were explained and confidentiality was guaranteed 
in order to encourage more detailed responses (Eisenhardt, 1989). Since an interest in the project is more likely to elicit valuable information, we offered our interviewees the incentive of access to the final results was offered (Miller et al., 1997).

A total of 85 firms and supporting organisations located in Toy Valley agreed to collaborate; we achieved a response rate of $95 \%$ of the total population identified from the reliable databases (SABI, AIJU and AEFJ). Toy manufacturers accounted for $45.88 \%$ of firms, with suppliers and local organisations accounting for $42.36 \%$ and $11.76 \%$ of firms respectively. Peer debriefing by AIJU's experts confirmed that all relevant players were considered and missing actors were scarce. The interview phase finished in 2015.

Since the relational data collected refer to two different networks, we organised them in two matrices of 85 rows and 85 columns, corresponding to the number of firms and local organisations in the cluster. The cells in the matrix show 1 for the existence of a tie between actor (i) in the row to actor (j) in the column and 0 otherwise. The matrix is asymmetric since the transfer of knowledge from actor (i) to actor (j) is not always bi-directional.

\subsection{Variables}

In addition to the descriptive data collected and in order to analyse the relational structure of each participant firm, we applied Social Network Analysis (SNA) via UCINET v.6 software (Borgatti et al., 2002). This technique has been used for cluster analysis by several researchers (Giuliani, 2007; Morrison and Rabellotti, 2009). It is a tool that allows exploration of the structural properties of a network (Wasserman and Faust, 1994). In line with Boschma and Ter Wal (2007), we follow an ego-network approach. An ego-network or EGONET is a part of a cluster network that consists of a firm (ego), all its relations to other firms (alters), and the relationships among them. Rather than focusing on the whole network, we analyse the relationships surrounding the ego to examine their content and structure and then relate these properties to ego performance.

Table 1 presents the set of variables for the firms in the cluster used to investigate the research questions.

Table 1 Variables analysed for research questions

\begin{tabular}{lll}
\hline $\begin{array}{l}\text { Research } \\
\text { question }\end{array}$ & Variable & Description \\
\hline RQ1 & Turnover & Turnover of the firm in 2015 \\
\hline RQ1 & Number of employees & Number of employees of the firm in 2015 \\
\hline RQ1 & Total assets & Total assets of the firm in 2015 \\
\hline RQ1 & Age & Age of the firm \\
\hline RQ2 & $\begin{array}{l}\text { BN EGONET size } \mid \text { KN EGONET } \\
\text { size }\end{array}$ & $\begin{array}{l}\text { Size of the firm's EGONET in the business } \\
\text { network | knowledge network }\end{array}$ \\
\hline RQ2 & $\begin{array}{l}\text { BN EGONET density } \mid \text { KN } \\
\text { EGONET density }\end{array}$ & $\begin{array}{l}\text { Density of the firm's EGONET in the } \\
\text { business network | knowledge network }\end{array}$ \\
\hline RQ2 & KN EGONET Structural holes & $\begin{array}{l}\text { Structural holes existing in the firm's } \\
\text { EGONET in the knowledge network }\end{array}$ \\
\hline RQ3 & $\begin{array}{l}\text { BN Manufacturers } \mid \text { KN } \\
\text { Manufacturers }\end{array}$ & $\begin{array}{l}\text { Number of ties of the firm with other } \\
\text { manufacturers in the business network } ~ \\
\text { knowledge network }\end{array}$ \\
\hline
\end{tabular}


Table 1 Variables analysed for research questions (continued)

\begin{tabular}{lll}
\hline $\begin{array}{l}\text { Research } \\
\text { question }\end{array}$ & Variable & Description \\
\hline RQ3 & $\begin{array}{l}\text { BN Raw materials suppliers } \mid \mathrm{KN} \\
\text { Raw materials suppliers }\end{array}$ & $\begin{array}{l}\text { Number of ties of the firm with raw materials } \\
\text { suppliers in the business network } \mid \text { knowledge } \\
\text { network }\end{array}$ \\
\hline RQ3 & $\begin{array}{l}\text { BN Specialised suppliers } \mid \mathrm{KN} \\
\text { Specialised suppliers }\end{array}$ & $\begin{array}{l}\text { Number of ties of the firm with specialised } \\
\text { suppliers in the business network } \mid \text { knowledge } \\
\text { network }\end{array}$ \\
\hline RQ3 & BN Institutions $\mid$ KN Institutions & $\begin{array}{l}\text { Number of ties of the firm with institutions in } \\
\text { the business network } \mid \text { knowledge network }\end{array}$ \\
\hline RQ3 & BN Homophily $\mid$ KN Homophily & $\begin{array}{l}\text { Degree in which the firm establishes } \\
\text { relationships with similar firms in the } \\
\text { business network } \mid \text { knowledge network }\end{array}$ \\
\hline
\end{tabular}

\section{Results and discussion}

\subsection{The cluster business and knowledge networks: main measures}

Before addressing our three research questions, we examine the structure of the relationship networks analysed and their main indicators. This allows a better understanding of the object of study and the results obtained.

Table 2 Main measures of the cluster networks

\begin{tabular}{lcc}
\hline Indicator & Business network & Knowledge network \\
\hline Density & $19.10 \%$ & $19.30 \%$ \\
Total ties & 1362 & 1379 \\
Average degree & 16.02 & 16.22 \\
Isolated nodes & 0 & 0 \\
Gini index & .37 & .41 \\
Reciprocity & $25.53 \%$ & $21.39 \%$ \\
\hline
\end{tabular}

Table 2 shows that both networks show important levels of interaction, which confirms that the companies have developed significant business and knowledge exchange relations. Table 2 also confirms the density of these networks, that is, the proportion of ties in the network compared to the total number of possible ties is similar in both the business network (19.10\%) and the knowledge network (19.30\%). From this we can deduce that the cluster firms in the sample tend to establish the same level of business and knowledge relations. This is corroborated by the similar number of links in these networks. This contrasts with the findings in other contexts (Giuliani, 2007; RamírezPasillas, 2010; Molina-Morales et al., 2012), perhaps because successful business ties require more knowledge ties. Toy manufacture often involves complex, technical and innovative activities that require the collaboration of suppliers. This generally is driven by knowledge and information flows. However, the coexistence of these two networks 
could have detrimental effects (Belso-Martínez et al., 2017). The overlaps of technical and business linkages foster tie strength and density and might leave knowledge exchanges to different tie links.

In order to confirm this, we explore the degree to which the existing pattern of interactions in the firms' business network is aligned to the pattern of interactions in the knowledge exchange network. To conduct this analysis, we observe the degree of overlap between the relations in both networks using UCINET's QAP (Quadratic Assignment Procedures) and following Friedkin (2009). QAP is a statistical technique that highlights the correlations between two square matrixes and is commonly used to analyse patterns of association among networks (Krackhardt, 1987). Specifically, we use Pearson and Jaccard correlation coefficients as indicators of overlap. Their values, interpreted as percentages, range between 0 and 1 such that the closer to 1 , the higher the degree of overlap between the networks. The results reveal a statistically significant correlation with a high degree of overlap between the relations explored. In particular, they show a level of overlap of $50 \%$ according to the Pearson coefficient, and $42.6 \%$ according to the Jaccard coefficient. Therefore, the results confirm the tendency for dual business and knowledge relationships in the cluster.

Finally, we focus on Gini and reciprocity indexes. The Gini concentration index shows whether there are some firms with a higher number of contacts than some other firms. The results indicate a degree of heterogeneity in the number of bonds per firm, and the results are similar for both networks. Reciprocity measures the number of bonds within a given network that are reciprocal. The presence of reciprocal exchanges makes bonds much more stable and reliable. The results show that reciprocity is somewhat higher in the business network (25.53\%) compared to the knowledge network $(21.39 \%)$, although in neither case are the values high.

\subsection{Addressing the research questions}

To address our three research questions, we compared MNE subsidiaries with other manufacturing cluster firms because of their similar position in the value chain. We compared three different groups, MNE Subsidiaries $(n=6)$, Domestic MNE $(n=4)$ and Local Manufacturers $(n=29)$, across the set of variables in Table 1. Since the groups of firms are not homogeneous and the requirements for an ANOVA test cannot be met, we perform a non-parametric test on the data. Thus, computation of a Kruskal-Wallis test $(\mathrm{H})$ is used to determine whether there are significant differences among the cluster firm groups (Kruskal and Wallis, 1952). The Kruskal-Wallis test ${ }^{2}$ compares three or more samples and indicates whether the distribution of at least one of them is different from the others. Where differences were found, we conducted an additional post-hoc analysis to identify particularities.

\subsubsection{RQ1: structural characteristics of MNEs subsidiaries}

Mean rank Turnover, Number of employees and Total assets scores are statistically significantly different between the different groups. In order to examine differences between groups, pair-wise comparisons were performed using Dunn's (1964) procedure with a Bonferroni correction for multiple comparisons. This post-hoc analysis reveals statistically significant differences in the scores for Turnover, Number of employees and 
Total assets between the MNE Subsidiaries and Local Manufacturers groups, and Domestic MNEs and Local Manufacturers groups, but not between the MNE Subsidiaries and Domestic MNEs (see Table 3). These results suggest that MNEs, both MNE subsidiaries and domestic MNEs, are larger than Local Manufacturers. Although this result is expected, its implications in terms of networking behaviour are relevant.

First, large size legitimates organisations since local stakeholders tend to interpret it as the outcome of success (Baum and Oliver, 1991). Large companies have a privileged position in the cluster which favours their network integration and attracts relational, knowledge and human resources.

Second, local SMEs often depend on the resources of larger firms, which again gives the latter an influential position within the cluster network. In other words, the survival or birth in the cluster of new, small, specialised suppliers of raw materials and components becomes, to an extent, dependent on the survival and growth of the large companies and MNEs. There is empirical evidence in the literature of the strong influence of the presence or absence of large companies and MNEs throughout the different cluster life cycle stages such as birth and decline (Lazerson and Lorenzoni, 1999; Alberti, 2006; Belussi and Sedita, 2009).

Third, the size of large companies allows them accumulate more social capital and relational resources within the cluster. This can help MNEs to act as knowledge brokers with local SMEs, thus, increasing the cluster's internal connectivity.

Fourth, according to authors such as Bathelt et al. (2004), Gertler and Levitte (2005) and Huggins and Johnston (2010), large companies are more likely to act as nodes in the global pipelines through which knowledge flows into the region. MNEs acting as knowledge gatekeepers can improve the cluster's knowledge base and prevent lock-in effects (Grabher, 1993).

However, there are no significant differences for the variable Ageamon g the three groups. This is consistent with subsidiaries' location strategies: they tend to opt for takeovers of pre-existing cluster firms rather than greenfield investments which involve the parent company building its foreign from scratch.

Table 3 Kruskal-Wallis and Bonferroni-Dunn post-hoc tests statistics for descriptive variables

\begin{tabular}{|c|c|c|c|c|c|c|c|}
\hline \multirow{2}{*}{ Variable } & \multirow{2}{*}{$\chi^{2}$} & \multirow{2}{*}{$\begin{array}{c}M S^{b} \\
\text { mean rank }\end{array}$} & \multirow{2}{*}{$\begin{array}{l}D M^{C} \text { mean } \\
\text { rank }\end{array}$} & \multirow{2}{*}{$\begin{array}{c}L M^{d} \\
\text { mean rank }\end{array}$} & \multicolumn{3}{|c|}{ Pair-wise comparisons $^{a e}$} \\
\hline & & & & & $M S-D M$ & $M S-L M$ & $D M-L M$ \\
\hline Turnover & $20.009 * * *$ & 32.17 & 36.25 & 15.24 & $\begin{array}{c}-4.083 \\
(7.360)\end{array}$ & $\begin{array}{c}16.925^{* * * *} \\
(5.114)\end{array}$ & $\begin{array}{c}21.009 * * * \\
(6.081)\end{array}$ \\
\hline $\begin{array}{l}\text { Number of } \\
\text { employees }\end{array}$ & $20.108 * * *$ & 32.17 & 36.25 & 15.24 & $\begin{array}{l}-4.083 \\
(7.342)\end{array}$ & $\begin{array}{c}16.925 * * * \\
(5.101)\end{array}$ & $\begin{array}{c}21.009 * * * \\
(6.066)\end{array}$ \\
\hline Total assets & $21.349 * * *$ & 33.00 & 36.25 & 15.07 & $\begin{array}{l}-3.250 \\
(7.360)\end{array}$ & $\begin{array}{c}17.931 * * * \\
(5.114)\end{array}$ & $\begin{array}{c}21.181 * * * \\
(6.081)\end{array}$ \\
\hline Age & 1.382 & 22.75 & 24.75 & 18.78 & & & \\
\hline Sample size & & 6 & 4 & 29 & & & \\
\hline
\end{tabular}

Notes: $\quad{ }^{a}$ Significant at 0.1 level $(*)$; Significant at 0.05 level $(* *)$; Significant at 0.01 level $(* * *) ;{ }^{\mathrm{b}} \mathrm{MS}=\mathrm{MNE}$ Subsidiaries; ${ }^{\mathrm{c}} \mathrm{DM}=$ Domestic MNEs; ${ }^{\mathrm{d}} \mathrm{LM}=$ Local Manufacturers; ${ }^{\mathrm{e}}$ Top values are mean differences between groups and bottom values are standard errors. 


\subsubsection{RQ2: involvement of MNE subsidiaries in the cluster networks}

Following this description of the general characteristics of cluster business and knowledge networks, we next investigate the involvement of MNE subsidiaries in these networks.

A Kruskal-Wallis non-parametric test $(\mathrm{H})$ determines differences in the scores for all the variables in Table 4.

Table 4 Kruskal-Wallis and Bonferroni-Dunn post-hoc tests statistics for network involvement variables

\begin{tabular}{|c|c|c|c|c|c|c|c|}
\hline \multirow{2}{*}{ Variable } & \multirow{2}{*}{$\chi^{2}$} & \multirow{2}{*}{$\begin{array}{c}M S^{b} \\
\text { mean rank }\end{array}$} & \multirow{2}{*}{$\begin{array}{l}D M^{c} \text { mean } \\
\quad \text { rank }\end{array}$} & \multirow{2}{*}{$\begin{array}{c}L M^{d} \\
\text { mean rank }\end{array}$} & \multicolumn{3}{|c|}{ Pair-wise comparisons $^{a e}$} \\
\hline & & & & & $M S-D M$ & $M S-L M$ & $D M-L M$ \\
\hline $\begin{array}{l}\text { BN EGONET } \\
\text { size }\end{array}$ & $5.154^{*}$ & 13.08 & 29.75 & 20.09 & $\begin{array}{c}-16.667^{*} \\
(7.346) \\
\end{array}$ & $\begin{array}{l}-7.003 \\
(5.104) \\
\end{array}$ & $\begin{array}{c}9.664 \\
(6.070) \\
\end{array}$ \\
\hline $\begin{array}{l}\text { BN EGONET } \\
\text { density }\end{array}$ & $4.866^{*}$ & 20.17 & 22.28 & 8.75 & $\begin{array}{l}-2.109 \\
(7.360)\end{array}$ & $\begin{array}{l}11.412^{*} \\
(5.114)\end{array}$ & $\begin{array}{l}13.526^{*} \\
(6.081)\end{array}$ \\
\hline $\begin{array}{l}\text { KN EGONET } \\
\text { size }\end{array}$ & $5.320 *$ & 12.42 & 29.25 & 20.29 & $\begin{array}{c}-16.833^{*} \\
(7.350)\end{array}$ & $\begin{array}{l}-7.876 \\
(5.107)\end{array}$ & $\begin{array}{c}8.957 \\
(6.073)\end{array}$ \\
\hline $\begin{array}{l}\text { KN EGONET } \\
\text { density }\end{array}$ & $6.533 * *$ & 20.83 & 22.38 & 7.50 & $\begin{array}{l}-1.545 \\
(7.360)\end{array}$ & $\begin{array}{l}13.329^{*} \\
(5.114)\end{array}$ & $\begin{array}{c}14.879 * * \\
(6.081)\end{array}$ \\
\hline $\begin{array}{l}\text { KN EGONET } \\
\text { Structural holes }\end{array}$ & $4.720^{*}$ & 15.08 & 30.75 & 19.53 & $\begin{array}{c}-15.667^{*} \\
(7.359)\end{array}$ & $\begin{array}{l}-4.451 \\
(5.113)\end{array}$ & $\begin{array}{l}11.216 \\
(6.081)\end{array}$ \\
\hline Sample size & & 6 & 4 & 29 & & & \\
\hline
\end{tabular}

Notes: $\quad{ }^{a}$ Significant at 0.1 level $(*)$; Significant at 0.05 level $(* *)$; Significant at 0.01 level $(* * *) ;{ }^{\mathrm{b}} \mathrm{MS}=\mathrm{MNE}$ subsidiaries; ${ }^{\mathrm{c}} \mathrm{DM}=$ Domestic MNEs; ${ }^{\mathrm{d}} \mathrm{LM}=$ Local Manufacturers; ${ }^{\mathrm{e}}$ Top values are mean differences between groups and bottom values are standard errors.

To examine differences between groups, we perform pair-wise comparisons. This posthoc analysis reveals statistically significant differences in mean rank BN EGONET size and KN EGONET size scores between MNE Subsidiaries and Domestic MNEs. This larger ego-network size of domestic MNE increases access to different stocks of knowledge and learning opportunities, accelerating the development of innovation. This somewhat surprising evidence perhaps is indicative of the selectivity in subsidiaries' networking practices, which limits their portfolio of local partners to a privileged club of skilled suppliers that are well integrated. This finding is supported by Ferrero and Maffioli (2004) and Ivarsson and Alvstam (2005) who find that, in the case of specialised products, such as many of those goods related to the toy industry, subsidiaries tend to establish close relationships with a few, selected suppliers. On the other hand, the limited size of the ego networks of subsidiaries may be a reflection of the fact that subsidiaries' innovation activities are, at least in part, developed outside the cluster by the parent company or some other foreign subsidiary. This is consistent with the lower number of structural holes providing fresh knowledge in subsidiaries' ego-networks and is in line with Rasiah (2003) and others, which highlight that innovative processes developed by MNEs partly managed by the headquarters in collaboration with localised subsidiaries.

To conclude our investigation of this research question, we find differences in mean rank BN EGONET density and KN EGONET density scores between MNE's and Local Manufacturers. This suggests higher levels of interaction and strong behavioural 
pressures, which minimise opportunism and give rise to an atmosphere of trust. In combination, these aspects ease the transfer of fine grained, complex knowledge essential for innovation, but might also lead to pernicious effects in terms of redundancies and cognitive lock-in.

\subsubsection{RQ3: embeddedness of MNE subsidiaries in the cluster networks}

To investigate the third research question, we checked with which firms MNE subsidiaries were connected in the cluster. As already mentioned, the variables BN and $\mathrm{KN}$ Manufacturers, $\mathrm{BN}$ and $\mathrm{KN}$ Raw materials suppliers, $\mathrm{BN}$ and $\mathrm{KN}$ Specialised suppliers and $\mathrm{BN}$ and $\mathrm{KN}$ Institutions measure the number of business and knowledge ties of the firms in the sample with other organisations such as manufacturers, raw materials suppliers, specialised suppliers and institutions. The Kruskal-Wallis test shows that mean rank BN Manufacturers, BN Specialised suppliers, BN Homophily, KN Manufacturers, KN Specialised suppliers and KN Homophily scores are statistically significantly different across groups (Table 5).

Table 5 Kruskal-Wallis and Bonferroni-Dunn post-hoc tests statistics for variables related to ties characteristics

\begin{tabular}{|c|c|c|c|c|c|c|c|}
\hline \multirow{2}{*}{ Variable } & \multirow{2}{*}{$\chi^{2}$} & \multirow{2}{*}{$\begin{array}{c}M S^{b} \\
\text { mean } \\
\text { rank }\end{array}$} & \multirow{2}{*}{$\begin{array}{c}D M^{c} \\
\text { mean } \\
\text { rank }\end{array}$} & \multirow{2}{*}{$\begin{array}{c}L M^{d} \\
\text { mean } \\
\text { rank }\end{array}$} & \multicolumn{3}{|c|}{ Pair-wise comparisons $^{a e}$} \\
\hline & & & & & $M S-D M$ & $M S-L M$ & $D M-L M$ \\
\hline BN Manufacturers & $8.851 * *$ & 7.42 & 24.50 & 21.98 & $\begin{array}{c}-17.083 * \\
(7.342)\end{array}$ & $\begin{array}{c}-14.566^{* *} \\
(5.101)\end{array}$ & $\begin{array}{c}2.517 \\
(6.067)\end{array}$ \\
\hline $\begin{array}{l}\text { BN Raw materials } \\
\text { suppliers }\end{array}$ & 4.274 & 16.75 & 29.25 & 19.40 & & & \\
\hline $\begin{array}{l}\text { BN Specialised } \\
\text { suppliers }\end{array}$ & $6.540 * *$ & 30.42 & 22.12 & 17.55 & $\begin{array}{c}8.292 \\
(7.328)\end{array}$ & $\begin{array}{c}12.865^{* *} \\
(5.092)\end{array}$ & $\begin{array}{c}4.573 \\
(6.055)\end{array}$ \\
\hline BN Institutions & 1.219 & 20.25 & 25.75 & 19.61 & & & \\
\hline BN Homophily & $9.874 * * *$ & 6.92 & 18.50 & 22.91 & $\begin{array}{c}-11.583 * \\
(7.356)\end{array}$ & $\begin{array}{c}-15.997 * * * \\
(5.111)\end{array}$ & $\begin{array}{l}-4.414 \\
(6.078)\end{array}$ \\
\hline KN Manufacturers & $6.778 * *$ & 9.33 & 25.88 & 21.40 & $\begin{array}{l}-16.542 * \\
(7.344)\end{array}$ & $\begin{array}{l}-12.063^{*} \\
(5.103)\end{array}$ & $\begin{array}{c}4.478 \\
(6.068)\end{array}$ \\
\hline $\begin{array}{l}\text { KN Raw materials } \\
\text { suppliers }\end{array}$ & 1.125 & 19.58 & 25.38 & 19.34 & & & \\
\hline $\begin{array}{l}\text { KN Specialised } \\
\text { suppliers }\end{array}$ & $5.613^{*}$ & 29.00 & 24.12 & 17.57 & $\begin{array}{c}4.875 \\
(7.339)\end{array}$ & $\begin{array}{l}11.431^{*} \\
(5.099)\end{array}$ & $\begin{array}{c}6.556 \\
(6.064)\end{array}$ \\
\hline KN Institutions & 2.403 & 16.58 & 27.62 & 19.66 & & & \\
\hline KN Homophily & $7.482 * *$ & 8.33 & 20.88 & 22.29 & $\begin{array}{l}-12.542^{*} \\
(7.358)\end{array}$ & $\begin{array}{l}-13.960 * * \\
(5.112)\end{array}$ & $\begin{array}{l}-1.418 \\
(6.080)\end{array}$ \\
\hline Sample size & & 6 & 4 & 29 & & & \\
\hline
\end{tabular}

Notes: $\quad{ }^{a}$ Significant at 0.1 level $(*)$; Significant at 0.05 level $(* *)$; Significant at 0.01 level $(* * *) ;{ }^{\mathrm{b}} \mathrm{MS}=\mathrm{MNE}$ subsidiaries; ${ }^{\mathrm{c}} \mathrm{DM}=$ Domestic MNEs; ${ }^{\mathrm{d}} \mathrm{LM}=$ Local Manufacturers; ${ }^{\mathrm{e}}$ Top values are mean differences between groups and bottom values are standard errors. 
To examine the differences between groups, we performed pair-wise comparison. This revealed statistically significant differences in mean rank BN Manufacturers and KN Manufacturers scores between MNE subsidiaries and the other firms. This shows the greater propensity for MNE subsidiaries to establish links with companies that are not manufacturers. In other words, MNE subsidiaries are less interested in accessing the tangible and intangible resources of other manufacturers in the cluster and are more interested in information from suppliers to support their business strategy and allow the configuration of a 'club' of skilled partners.

The analysis shows differences in mean rank BN Specialised suppliers and $\mathrm{KN}$ Specialised suppliers scores between MNE Subsidiaries and Local Manufacturers. This confirms the previous assumptions. Overall, the type of suppliers in which MNE subsidiaries are interested are suppliers of raw materials and suppliers whose knowledge will enable a more efficient production process.

Finally, we examine homophily, that is, the extent to which firms establish relationships with similar firms in the networks; the results of the post-hoc test presents differences in mean rank BN Homophily and KN Homophily scores between MNE Subsidiaries and the other groups. Specifically, compared to the other firms in the cluster, MNE subsidiaries show a lower tendency to be lined in the business and knowledge networks to similar companies, in this case, manufacturers. These results are consistent with the previous analysis and reflect the tendency for MNE subsidiaries to establish close business and knowledge relationships with a limited set of specialised and skilled suppliers. This evidence is in line with the findings obtained in other empirical studies such as those focusing on the Italian mechanical industry in Brazil (Tunisini et al., 2011) and the Japanese automotive industry in Pakistan (Khan et al., 2015).

\section{Conclusions}

In light of the growing interest in the role of MNEs in industrial clusters, this paper examined MNEs' and MNE subsidiaries' involvement in mature clusters. We applied two different methodological approaches to the case of the Toy Valley cluster in Spain. The suitability of this combination to analyse the phenomenon reinforces the value of the empirical results obtained. Essentially, our findings suggest that domestic MNEs, MNE subsidiaries and local manufacturers are heterogeneous in their networking behaviour. Their networking practices are shaped mainly by local innovation activities and the firms' extra-cluster connectedness.

Compared to local manufacturers, both domestic MNEs and subsidiaries exhibit a pattern of rather dense networks characterised by frequent interactions and trust. These relational structures allow transfers of complex and specific knowledge that ease exploitation activities, but increase the risks of redundancies and cognitive lock in. In our view, domestic MNEs or MNE subsidiaries' privileged access to global knowledge, counterbalances the detrimental effects of excess density. Global knowledge captured and diffused by domestic MNEs and MNE subsidiaries, seems sufficient to sustain the innovativeness of their network. 
Networks of domestic MNEs and MNE subsidiaries show remarkable asymmetries in size. The larger size of the domestic multinationals is an interesting result. Considering that both types of firms are similar in age, this result may be related to the nature and intensity of their innovation activities. To sustain their innovation performance, domestic MNEs need access to more local repositories of knowledge. Thanks to the variety of local knowledge sources, domestic MNEs accumulate heterogeneous local knowledge which reduces the need for extra-cluster linkages that would involve a higher level of effort. Conversely, MNE subsidiaries' innovation activities are, to an extent, conducted in the MNE headquarters or rely on ubiquitous knowledge obtained through intra-firm flows. Thus, local linkages are relatively more limited. However, the availability of internal knowledge flows in subsidiaries does not eradicate the need for cluster-specific knowledge. Similarly, the MNE subsidiary network is comprised of local actors such as specialised suppliers, local supporting organisations and other subsidiaries. This suggests that these subsidiaries' location in mature clusters is driven more by knowledge aspects than costs. This reinforces the argument presented in the results section and empirical evidence on the presence of MNE subsidiaries in clusters according to their life cycle. Over time, MNE subsidiaries are integrated into the territory similar to other local companies, and are looking for other advantages beyond localisation costs.

Some policy implications at the cluster level can be inferred from the above findings. The selective nature of MNE subsidiaries' networking practices in the cluster leads them to interact with a limited number of companies, mainly specialised suppliers. Since large companies act as nodes in the global pipeline, public policies should aim to promote greater integration of MNE subsidiaries in the local context to allow increased flows of knowledge, which would foster innovation within the cluster and also internationalisation. Policy makers should try to embed MNE subsidiaries in the local territory and promote an environment of collaboration and specialisation that will attract additional firms in search of synergies. It is essential, also, that policy makers should be aware of the resources available in the territory in order to design appropriate policies.

From a managerial perspective, our work highlights the relevance of territory, local resources and relationships with other companies and agents, to access global value chains. Thus, greater embeddedness of the MNEs will facilitate access to the knowledge flows circulating within the network. Furthermore, in the case of MNE subsidiaries, these knowledge flows will allow innovation processes to be decentralised from the headquarters, speeding up activity and balancing intra and extra-firm relationships. Finally, in the case of small companies, the establishment of linkages with larger companies should improve their access to global value chains.

This paper has some limitations. First, the analysis focuses on only one cluster; comparative analyses with other clusters might reduce potential geo-industry bias, reinforce our findings and allow generalisation. Second, the paper focuses only on within cluster knowledge and business exchanges. Business and knowledge flows between subsidiary and parent or other extra-cluster firms are overlooked. Future studies could focus on networks that cross cluster boundaries, which should provide more valuable implications for both the subsidiary and the host territory. 


\section{References}

Albalalejo, M. (2002) 'Enhancing innovation capabilities in SME clusters: evidence from a service centre in Spain', in Van Dijk, M. and Sandee, H. (Eds): Innovation and Small Enterprises in the Third World, Edward Elgar, Cheltenham, pp.209-222.

Alberti, F.G. (2006) 'The decline of the industrial district of Como: recession, relocation or reconversion?', Entrepreneurship and Regional Development, Vol. 18, No. 6, pp.473-501.

Almeida, P. and Phene, A. (2004) 'Subsidiaries and knowledge creation: the influence of the MNC and host country on innovation', Strategic Management Journal, Vol. 25, Nos. 8/9, pp.847-864.

Amin, A. and Cohendet, P. (2004) Architectures of Knowledge: Firms, Capabilities, and Communities, University Press, Oxford.

Bathelt, H., Malmberg, A. and Maskell, P. (2004) 'Clusters and knowledge: local buzz, global pipelines and the process of knowledge creation', Progress in Human Geography, Vol. 28, No. 1, pp.31-56.

Baum, J.A.C. and Oliver, C. (1991) 'Institutional linkages and organizational mortality', Administrative Science Quarterly, Vol. 36, pp.187-218.

Belussi, F. and Sedita, S.R. (2009) 'Life cycle vs. multiple path dependency in industrial districts', European Planning Studies, Vol. 17, No. 4, pp.505-528.

Belso-Martínez, J.A., Mas-Tur, A. and Roig-Tierno, N. (2017) 'Synergistic effects and the coexistence of networks in clusters', Entrepreneurship \& Regional Development, Vol. 29, Nos. 1/2, pp.137-154.

Beugelsdijk, S., McCann, P. and Mudambi, R. (2010) 'Introduction: place, space and organizationeconomic geography and the multinational enterprise', Journal of Economic Geography, Vol. 10, No. 4, pp.485-493.

Beugelsdijk, S. and Mudambi, R. (2013) 'MNEs as border-crossing multi-location enterprises: the role of discontinuities in geographic space', Journal of International Business Studies, Vol. 44, No. 5, pp.413-426.

Birkinshaw, J. and Hood, N. (1998) 'Multinational subsidiary evolution: capability and charter change in foreign-owned subsidiary companies', Academy of Management Review, Vol. 23, No. 4, pp.773-795.

Birkinshaw, J. and Hood, N. (2000) 'Characteristics of foreign subsidiaries in industry clusters', Journal of International Business Studies, Vol. 31, No. 1, pp.141-154.

Borgatti, S.P., Everett, M.G. and Freeman, L.C. (2002) Ucinet for Windows: Software for Social Network Analysis, Analytic Technologies, Harvard, MA.

Boschma, R.A. and Ter Wal, A.L.J. (2007) 'Knowledge networks and innovative performance in an industrial district: the case of a footwear district in the South of Italy', Industry and Innovation, Vol. 14, No. 2, pp.77-199.

Cantwell, J. (2009) 'Location and the multinational enterprise', Journal of International Business Studies, Vol. 40, No. 1, pp.35-41.

Cantwell, J. and Mudambi, R. (2005) 'MNE competence-creating subsidiary mandates', Strategic Management Journal, Vol. 26, No. 12, pp.1109-1128.

Cantwell, J. and Mudambi, R. (2011) 'Physical attraction and the geography of knowledge sourcing in multinational enterprises', Global Strategy Journal, Vol. 1, Nos. 3/4, pp.206-232.

Cantwell, J. and Piscitello, L. (1999) 'The emergence of corporate international networks for the accumulation of dispersed technological competences', Management International Review, Vol. 39, No. 1, p.123

Collinson, S.C. and Wang, R. (2012) 'The evolution of innovation capability in multinational enterprise subsidiaries: dual network embeddedness and the divergence of subsidiary specialisation in Taiwan', Research Policy, Vol. 41, No. 9, pp.1501-1518. 
Crescenzi, R., Pietrobelli, C. and Rabellotti, R. (2013) 'Innovation drivers, value chains and the geography of multinational corporations in Europe', Journal of Economic Geography, Vol. 14, No. 6, pp.1053-1086.

Dunn, O.J. (1964) 'Multiple comparisons using rank sums', Technometrics, Vol. 6, No. 3, pp.241-252.

Eisenhardt, K. (1989) 'Building theories from case study research', The Academy of Management Review, Vol. 14, No. 4, pp.532-550.

Enright, M.J. (2000) 'Regional clusters and multinational entreprises: independence, dependence, or interdependence', International Studies of Management \& Organization, Vol. 30, No. 2 , pp.114-138.

Ferrero, L. and Maffioli, A. (2004). The interaction between foreign direct investment and small and medium-sizedenterprises in Latin America and the Caribbean: a look at regional innovation systems, Inter-American Development Bank, Special Office in Europe, París.

Figueiredo, P.N. (2011) 'The role of dual embeddedness in the innovative performance of MNE subsidiaries: evidence from Brazil', Journal of Management Studies, Vol. 48, No. 2 , pp.417-440.

Friedkin, N.E. (2009) 'Jaccard-spline index of structural proximity in contact networks', Social Networks, Vol. 31, No. 1, pp.76-84.

Gertler, M.S. and Levitte, Y.M. (2005) 'Local nodes in global networks: the geography of knowledge flows in biotechnology innovation', Industry \& Innovation, Vol. 12, No. 4, pp.487-507.

Giuliani, E. (2007) 'The selective nature of knowledge networks in clusters: evidence from the wine industry', Journal of Economic Geography, Vol. 7, No. 2, pp.139-168.

Grabher, G. (1993) 'The weakness of strong ties; the lock-in of regional development in the Ruhr area', in Grabher, G. (Ed.): The Embedded Firm; on the Socioeconomics of Industrial Networks, Routledge, London/New York, pp.255-277.

Heidenreich, M. (2012) 'The social embeddedness of multinational companies: a literature review', Socio-Economic Review, Vol. 10, No. 3, pp.549-579.

Hervás-Oliver, J.L. and Sempere-Ripoll, F. (2016) 'Cognitive inertia at bay: global value chain and cluster openness favouring smart specialization in the Toy Valley cluster-Spain', in Belussi, F. and Hervás-Oliver, J.L. (Eds): Unfolding Cluster Evolution, Routledge, NY, pp.106-116.

Holm, U., Malmberg, A. and Sölvell, Ö. (2003) 'Subsidiary impact on host-country economies: the case of foreign-owned subsidiaries attracting investment into Sweden', Journal of Economic Geography, Vol. 3, No. 4, pp.389-408.

Holmström, M. (2006) 'Globalisation and good work: IMPIVA, a Spanish project to regenerate industrial districts', Economische en Sociale Geografie, Vol. 97, No. 5, pp.491-502.

Huggins, R., and Johnston, A. (2010) 'Knowledge flow and inter-firm networks: the influence of network resources, spatial proximity and firm size', Entrepreneurship \& Regional Development, Vol. 22, No. 5, pp.457-484.

Ivarsson, I. and Alvstam, C.G. (2005) 'The effect of spatial proximity on technology transfer from TNCs to local suppliers in developing countries: the case of AB Volvo in Asia and Latin America', Economic Geography, Vol. 81, No. 1, pp.83-111.

Khan, Z., Shenkar, O. and Lew, Y.K. (2015) 'Knowledge transfer from international joint ventures to local suppliers in a developing economy', Journal of International Business Studies, Vol. 46, No. 6, pp.656-675.

Krackhardt, D. (1987) 'QAP partialling as a test of spuriousness', Social Networks, Vol. 9, No. 2, pp.171-186.

Kruskal, W.H. and Wallis, W.A. (1952) 'Use of ranks in one-criterion variance analysis', Journal of the American Statistical Association, Vol. 47, No. 260, pp.583-621.

Lazerson, M. and Lorenzoni, G. (1999) 'Resisting organizational inertia: the evolution of industrial districts', Journal of Management and Governance, Vol. 3, No. 4, pp.361-377. 
Marin, A. and Bell, M. (2010) 'The local/global integration of MNC subsidiaries and their technological behaviour: Argentina in the late 1990s', Research Policy, Vol. 39, No. 7, pp.919-931.

Mariotti, S., Piscitello, L. and Elia, S. (2010) 'Spatial agglomeration of multinational enterprises: the role of information externalities and knowledge spillovers', Journal of Economic Geography, Vol. 10, No. 4, pp.519-538.

McCann, P. and Acs, Z.J. (2011) 'Globalization: countries, cities and multinationals', Regional Studies, Vol. 45, No. 1, pp.17-32.

McCann, P. and Mudambi, R. (2004) 'The location behavior of the multinational enterprise: some analytical issues', Growth and Change, Vol. 35, No. 4, pp.491-524.

Meyer, K.E., Mudambi, R. and Narula, R. (2011) 'Multinational enterprises and local contexts: the opportunities and challenges of multiple embeddedness', Journal of Management Studies, Vol. 48, No. 2, pp.235-252.

Miller, C., Cardinal, L. and Glick, W. (1997) 'Retrospective reports in organizational research: a reexamination of recent evidence', Academy of Management Journal, Vol. 40, No. 1, pp.189-204.

Molina-Morales, F.X., Capó-Vicedo, J., Tomás-Miquel, J.V. and Expósito-Langa, M. (2012) 'Análisis de las redes de negocio y de conocimiento en un distrito industrial. Una aplicación al distrito industrial textil valenciano', Cuadernos de Economía y Dirección de la Empresa, Vol. 15, No. 2, pp.94-102.

Morrison, A. and Rabellotti, R. (2009) 'Knowledge and information networks in an Italian wine cluster', European Planning Studies, Vol. 17, No. 9, pp.983-1006.

Mudambi, R. (2008) 'Location, control and innovation in knowledge-intensive industries', Journal of Economic Geography, Vol. 8, No. 5, pp.699-725.

Mudambi, R., Mudambi, S.M. and Navarra, P. (2007) 'Global innovation in MNCs: the effects of subsidiary self-determination and teamwork', Journal of Product Innovation Management, Vol. 24, No. 5, pp.442-455.

Mudambi, R. and Navarra, P. (2004) 'Is knowledge power? Knowledge flows, subsidiary power and rent-seeking within MNCs', Journal of International Business Studies, Vol. 35, No. 5, pp.385-406.

Mudambi, R. and Swift, T. (2012) 'Multinational enterprises and the geographical clustering of innovation', Industry \& Innovation, Vol. 19, No. 1, pp.1-21.

Mudambi, R. and Venzin, M. (2010) 'The strategic nexus of offshoring and outsourcing decisions', Journal of Management Studies, Vol. 47, No. 8, pp.1510-1533.

Nadvi, K. and Halder, G. (2005) 'Local clusters in global value chains: exploring dynamic linkages between Germany and Papista', Entrepreneurship and Regional Development, Vol. 17, No. 3 , pp.339-363.

Narula, R. (2014) 'Exploring the paradox of competence-creating subsidiaries: balancing bandwidth and dispersion in MNEs', Long Range Planning, Vol. 47, Nos. 1/2, pp.4-15.

Porter, M.E. (1998) 'Clusters and the new economics of competition', Harvard Business Review, Vol. 76, No. 6, pp.77-90.

Ramírez-Pasillas, M. (2010) 'International trade fairs as amplifiers of permanent and temporary proximities in clusters', Entrepreneurship and Regional Development, Vol. 22, No. 2, pp.155-187.

Rasiah, R. (2003) 'Industrial technology transition in Malaysia', in Lall, S. and Urata, Sh. (Eds): Competitiveness, Foreign Direct Investment and Technological Activity in East Asia, Cheltenham, Elgar, pp.305-333.

Tallman, S. and Chacar, A.S. (2011) 'Communities, alliances, networks and knowledge in multinational firms: a micro-analytic framework', Journal of International Management, Vol. 17, No. 3, pp.201-210. 
Tunisini, A., Bocconcelli, R. and Pagano, A. (2011) 'Is local sourcing out of fashion in the globalization era? Evidence from Italian mechanical industry', Industrial Marketing Management, Vol. 40, No. 6, pp.1012-1023.

Wasserman, S. and Faust, K. (1994) Social Network Analysis. Methods and Applications, Cambridge University Press, Cambridge.

Zangh, F., Cantwell, J. and Jiang, G. (2014) 'The competence creation of recently-formed subsidiaries in networked multinational corporations: comparing subsidiaries in China and subsidiaries in industrialized countries', Asian Business \& Management, Vol. 13, No. 1, pp.5-41.

\section{Notes}

1 The respective questions read as follows: a) From which of the following firms on the list did you regularly ask technical advice? b) With which of the following firms on the list have you established regular business relationships?

2 Since the distribution of the scores for each variable analysed differ for the three groups (as can be seen from a visual inspection of the boxplot, we conducted multiple comparisons of the mean ranks for all the variables and groups. 